\title{
Revamping Vocational and Technical Education in Nigeria for Sustainable Development
}

\author{
Ukuma, Solomon \\ Department of Technical Education, \\ College of Education, Katsina-Ala, Nigeria \\ Ochedikwu, John Ochinyabo \\ Vocational and Technical Education Department \\ Benue State University, Makurdi-Nigeria \\ Deke, Gabriel Nyitar \\ Department of Technical Education, \\ College of Education, Katsina-Ala, Nigeria
}

\section{Doi:10.5901/mjss.2013.v4n12p55}

\section{Abstract}

The paper is on revamping Vocational and Technical Education in Nigeria for sustainable development. The paper discussed how the signs in vocational and technical education sub-sector are not encouraging for instance lack of qualified vocational and technical education teachers, lack of workshops, machines, hand tools and other infrastructures in view of the above, technical and vocational education is preached by various successive governments since independence in Nigeria institutions of learning and not practiced. The paper discussed vocational and technical education instructional delivery for empowerment and employment and instructions should be geared towards self reliant of Nigerian citizens in future and it would also enhance scientific and technological development for actualization of vision 20:2020. The paper also discussed vocational and technical education research and development (R\&D) as a means of global economic recovery and sustainable development in Nigeria. R\&D would bring about innovative ideas, techniques, skills and professional suggestions to revamp vocational and technical education. Finally, the paper concludes that, research should be conducted in vocational and technical education and recommendations faithfully implemented to the later for greater service delivery for sustainable national development in Nigeria.

Keywords: Revamping Vocational and Technical Education, Sustainable Development.

\section{Introduction}

Vocational and Technical education is the hub of any economy of a nation just as the wheel rotates around the hub, the economic sector of Nigeria rotates around vocational and technical education considering the current socio-economic, scientific and technological development of Nigeria. Rashtriya (2005) pointed out that, the wealth and prosperity of a nation depends on the effective utilization of its human and material resources through industrialization. Rashtriya maintained further that, the use of human material for industrialization demands its education skills. Industry opens up possibilities of greater fulfillment for the individual. India's resources of manpower can only become an asset in the modern world when trained and educated.

For over 52 years, Nigerians are quietly hopeful that there would soon be a revamping process in 
vocational and technical education sub-sector. Revamping process in vocational and technical education must happen to save our country's economy. The signs in vocational and technical education sub-sector are not very encouraging. For instance, lack of qualified vocational and technical education teachers, lack of workshops or laboratories, lack of machines, equipment, hand tools and other infrastructures. Vocational and technical education is preached by various successive governments since independence in Nigeria institutions of learning and not practiced. But if vocational and technical education is practiced as it is done in China, India, Canada, United States of America and Germany, it would pave the way for a radical change in Nigeria entire economic system and this would enhance sustainable scientific and technological development of Nigeria.

Revamping Vocational and Technical Education is a process of applying scientific knowledge into vocational and technical education sub-sector in Nigeria with a view of identifying, studying, analyzing, evaluating and continuing or terminating vocational and technical education programme. Furthermore, revamping vocational and technical education involves among other things, the development of policy alternatives, experimenting, implementing and feedback and revamping vocational and technical education must meet the needs and aspirations of the citizens of Nigeria.

According to Ogwo and Oranu (2006) the terms vocational and technical education are used jointly or synonymously to mean education geared towards skill acquisition for gainful employment.

Similarly, Olaitan, Nwachukwu, Igbo, Onyemachi and Ekong (1999) defined vocational and technical education as education for work; its value is therefore rooted in the worthwhile living in the world of work. Apart from work, vocational and technical education prepared learners to develop profitable social habits required by the society.

Also, Okoro (1999) said vocational and technical education is often used interchangeably to refer to the same type of education. Technical education is special grades of vocational education which can be distinguished from other vocational education programmes because more mathematics and science are required in the training programmes usually bridge the gap between the professional engineer and the crafts man. Vocational and technical education adequately prepared the individual in skills, techniques, knowledge and attitudes for effective employment in the world of work place.

\section{Vocational and Technical Education Instructions for Empowerment and Employment for Sustainable Development in Nigeria}

The needed changes in vocational and technical education instructional delivery for empowerment and employment could be achieved by organizing vocational and technical education seminars or conferences primarily to help vocational and technical education teachers become acquainted with the essential skills and experiences of composite engineering products household and other engineering technology items construction. It should be open to any person in other field of study like sociology wishing to develop his/her skills and techniques or background in vocational and technical education.

Furthermore, it is pertinent to note that, institutions of learning in Nigeria should begin to prepare their under graduate and graduate students in the use of the computer as an instructional tool. This may be difficult, however, because, lack of funding in vocational and technical education sub-sector is one of the reason or barriers to computer use in institutions of learning in Nigeria.

Supporting the above, craft (2002) argues that;

Research evidence concerning the effectiveness of computer assisted instruction is very far from conclusive, however, the available research and vast amount of practical evidence indicate that computer assisted instruction has a tremendous potential. Educators should be encouraged to implement it. Computer assisted instruction and other classroom activities using the computer literacy a worthy goal of all schools preparing students for a computer intensive society. 
Change in vocational and technical education cannot be complete without adequately providing unique experiences such as research design and actual construction of project, practicing problem solving with materials and gaining information on the world of work place in line with global standard or challenges. Vocational and technical education in Nigeria and globally is a unique area in educational sector that should teach not only occupational clusters and general conceptual knowledge but can also foster adaptability, build technical literacy and provide leisure skills through experience.

The changes in vocational and technical education instructional delivery should be geared towards empowerment, job creation, and self reliant of Nigeria citizens in future and would also enhance scientific and technological development for actualization of vision 20:2020. Vocational and technical education should be able to teach us a variety of sellable useful skills as well as imbibe good maintenance culture for the few machines or tools that are available.

If vocational and technical education instructions are restricted to computer in various institutions of learning, vocational and technical education graduates in Nigerian institutions would have a broad conceptual understanding of the structuring and functions of both the institutions of learning and industries as well as the fundamental skills of communication, mathematics and problem solving or practical skills will be the versatile, trainable, adaptable and satisfied workers of our institutions of learning and industries, companies and factories today which would enhance better performance, empowerment, create jobs and improve higher productivity of the Nigeria economy.

Similarly, Ferguson (2009) agreed with the needed changes in vocational and technical education instructional delivery for employment and self employment. When he argued that, although future workers may have to perform fewer unpleasant tasks such as repetitive welding, painting and furnace loading, they will have to be more skilled than their predecessors.

Vocational and technical education administrators can lead the way in bringing about needed changes in instructional delivery for empowerment and job creation for sustainable national development. Most vocational and technical education administrators are limited only by their vision and imagination in ways that they can promote meaningful changes or instructional delivery through technical and vocational education programme(s) improvement for sustainable national development and if this is actualize, it would automatically enhance our actualization of transformation agenda of the government and Vision 20:2020 for sustainable development of Nigeria.

\section{Vocational and Technical Education Research and Development (R\&D) as a Means of Global Economic Recovery for Sustainable Development}

Every year, billions of naira are been spent for the importation of vehicle or cars, food, agricultural implements, electronics even razor blades from Shangai-China, in fact, virtually every thing. Meanwhile, the field of vocational and technical education is not growing rapidly through technical and vocational education reliable and accurate researches. The national master plan for vocational and technical education (TVE) development in Nigeria in the $21^{\text {st }}$ century (FGN 2000) stated that, good policies are on ground, particularly in the various national development plans but, these are never faithfully implemented. The main reason for this is the non-inclusion of plan implementation studies as a major component of project/programme proposal. Similarly, Okogie (2007) rightly pointed out that, most of the lecturers have refused to update their knowledge through quality research and going on sabbatical to meet current demand in the educational system. How can a lecturer from Ambrose Ali University Ekpoma go for sabbatical in University of Benin? What will he learn from almost the same environment, nothing new? Again, I am surprised when lecturers do Ph.D for almost 15 years. Some are even doing the same thing I did 21 years ago for my Ph.D thesis.

Even though, conducting research in vocational and technical education in Nigeria is not taken serious, the potential of research and its capability on Nigeria economic advancement is not well-appreciated or organized as a mean of eradicating poverty and actualizing vision 20:20:20. It is on this ground that, Ukuma 
(2009) put it,

Vocational and Technical Education research had suffered neglect and under investment in the last 49 years. The dreams of Nigeria's at independence in 1960 for a country that will free her citizens from all sort of scientific, technological, political and socio-economic bondage was yet to come true, Nigeria at 49 years after independence has nothing to show case in terms of vocational and technical education development. We still imports vehicles spare parts, all our four refineries are not operating or producing at normal capacity, inadequate electricity supply to mention but a few.

The complexities that burden the successful and quality research conduction so as to re-engineer vocational and technical education can not be overemphasized. This has been the phenomenon that has affected the development of Nigeria. It is at this critical time that research in vocational and technical education is important in Nigeria, various questions are being asked why government funds and international partner agencies continue to channel resources rounds after rounds on the entire vocational and technical education programme and no reasonable result is coming out.

The answer to this question bothering the minds of many Nigerians is that, there is need to ensure that the investment made by Nigerian Government and partner agencies on vocational and technical education research last forever and Nigeria becomes a developed state or nation and actualize vision 20:2020. It is pertinent to continue to advocate for the revamping of vocational and technical education and conduct research for Nigerian citizens to be self reliance.

Scheefer and Moss (2008) pointed out that, Universities, Polytechnics and Colleges of Education have used funds or finances allocated for them to established vocational and technical education programmes instead they used it to established other courses. Money or funds for research related activities are either controlled by some of the chief executive officers of the institutions and must of these permitted usually must have immediate application in the classroom.

The role of Nigerian Universities, Polytechnics, Colleges of Education and research institutions throughout 52 years have not made much significant contributions to vocational and technical education which is aimed at preparing Nigeria citizens for acquisition of skills and techniques that could lead to self empowerment and employment in the global labour market.

It is unfortunate that, in Nigeria, not all Universities and other tertiary institutions of learning of comparable standing have established vocational and technical education courses or programmes. Research in vocational and technical education if conducted would have generated new ideas, identify, interpret and organize these ideas of scholars from other fields that would lead to the improvement of practice in the vocational and technical education for economic empowerment, job creation and to actualize vision 20:2020.

\section{Conclusion}

Vocational and technical education could only be revamped if we improve on our dilapidated infrastructure in our institution of learning, entrench transparency in economic management of funds allocated to vocational and technical education at various levels of education, good policy formulation, supervision, monitoring and implementing vocational and technical education programmes.

Vocational and technical education revamping, if vigorously pursued would enhanced speedy diversification of our economy which would enhance the actualization of the Millennium Development Goals (MDGS) and Vision 20:2020 for sustainable development of Nigeria.

Finally, the hand writing is on the wall and it is getting larger and clear, Nigerians over dependence on oil just has to stop forth with and the government should develop a framework to safeguard our economy by revamping vocational and technical education for economic recovery, self reliance, sustainability and a key for national development through vocational and technical education should be irreversible for sustainable development. 


\section{Suggestions/Recommendations}

* All institutions of learning in Nigeria should use the multimedia, computer simulation techniques and E-learning instructional approach which involve the use of electronic medium for instruction. The Elearning instructional medium include, internet, intranet, satellite broadcast, CD ROM, video tape, etc. this would enhanced the needed change in vocational and technical education instructional delivery for empowerment and employment in the global labour market.

* Vocational and Technical education reliable researches should be conducted and recommendations faithfully implemented to the later. Also lecturers and teachers should update their knowledge through quality research and going on sabbatical leave abroad or to developed countries to meet current demand in vocational and technical education in particular and in the educational system in general for sustainable development.

* All Universities, Polytechnics, Colleges of Education in Nigeria should forth with establish technical and vocational education courses for empowerment, employments for economic recovery, job creation for sustainable development of Nigeria.

\section{References}

Craft, C.O. (2002) Research on the use of computer assisted instruction. Journal of the American Industrial Technology Association 41, 26-27.

Ferguson, (2009, November 9). New York Daily Newspaper, p20.

National Master Plan for Technical and Vocational Education (TVE) Development in Nigeria in the 21 ${ }^{\text {st }}$ Century with the Blueprint for the Decade 2001-2010. Abuja: Federal Ministry of Education publishers.

Olaitan, S.O, Nwachukwu, C.E. Igbo, C.A., Onyemachi, G.A., and Ekong, A.O. (1999) Curriculum Development and Management in Vocational Technical Education. Onitsha: Cape publishers International limited.

Ogwo, B.A. and Oranu R.N. (2006) Methodology in Formal and Non-formal Technical/Vocational Education. Nsukka: University of Nigeria Press Ltd.

Okogie, J. (2007, November 6) Vanguard Newspaper, p.14.

Okoro, O.M. (1999) Principles and Method in Vocational and Technical Education. Nsukka: University Trust Publisher.

Rashtriya, G. (2005) Women Education. New Delhi A.P.H. Publishing Corporation.

Schaefer, C. and Moss, J. (2008). The Role of Universities in Vocational Education. Journal of Vocational Education 13,49-54.

Ukuma, S. (2009) Research in Vocational Technical Education; A Strategy to Sustain Competitiveness in the Global Economy for National Developments. African Journal of Indigenous Development 5,24-258. 
